This item was submitted to Loughborough's Research Repository by the author.

Items in Figshare are protected by copyright, with all rights reserved, unless otherwise indicated.

\title{
The politics of trans-national belonging: A study of the experiences of second-generation Egyptians during a period of socio-political change in Egypt
}

\section{PLEASE CITE THE PUBLISHED VERSION}

http://dx.doi.org/10.1093/migration/mnv019

\section{PUBLISHER}

(C) The Authors 2015. Published by Oxford University Press

\section{VERSION}

AM (Accepted Manuscript)

\section{PUBLISHER STATEMENT}

This work is made available according to the conditions of the Creative Commons Attribution-NonCommercialNoDerivatives 4.0 International (CC BY-NC-ND 4.0) licence. Full details of this licence are available at: https://creativecommons.org/licenses/by-nc-nd/4.0/

\section{LICENCE}

CC BY-NC-ND 4.0

\section{REPOSITORY RECORD}

Saey, Sarah, and Michael Skey. 2019. "The Politics of Trans-national Belonging: A Study of the Experiences of Second-generation Egyptians During a Period of Socio-political Change in Egypt". figshare.

https://hdl.handle.net/2134/21996. 
The politics of trans/national belonging: A study of the experiences of secondgeneration Egyptians during a period of profound socio-political change in Egypt

\begin{abstract}
Building on insights from recent research on 'return mobilities' among the second generation, this paper addresses the trans-national practices of young British and American-born people of Egyptian ancestry and, in particular, their experiences in Egypt during a time of great social and political upheaval. In observing the ways in which many of these individuals effectively operate in their parent's homelands by drawing on Western credentials or established social networks, we also note how intersections of gender, religion, class and nationality sometimes constrain these activities. In the process, attention is drawn to the hierarchies of belonging that structure trans-national fields and the degree to which struggles for recognition and status are shaped by the demands of host populations, notably during periods when social identities come under sustained scrutiny.
\end{abstract}

Keywords: Transnationalism, Second generation, ‘Return’ Migration, Politics of Belonging, Egypt, Arab Spring, Belonging,

\title{
Introduction
}


Over the past two decades, scholars have begun to develop more sophisticated frameworks for tracking the experiences and shifting allegiances of those whose lives are increasingly lived across borders (Portes et al, 1999, Levitt \& Jaworsky, 2007, King \& Christou, 2011). Of particular relevance here, is the growing body of work addressing the activities of second and third generations who 'return' to their grand/parent's homelands over, and sometimes for, extended periods of time (Conway \& Potter, 2009, Levitt, 2009, Christou, 2011).

In this paper, we draw on interview data from a study of British and American-born people of Egyptian ancestry and explore their transnational practices, with a particular focus on their experiences of living in Egypt during a period of profound social change. In focusing on a relatively under-studied region of the world, we are able to offer fresh insights into the ways in which more 'universalised' forms of trans/national capital ${ }^{\mathrm{i}}$ are deployed and converted, whether for instrumental or existensial purposes, in more challenging social and economic settings. At the same time, we show that established institutional and vernacular frameworks, associated with gender, religion, class and nationality, constrain the activities of these transnational actors and, at particular moments, position them as 'outsiders' with all the economic and psycho-social costs this entails. Such an approach emphasises the hierarchies of belonging that shape people’s lives across trans-national settings (Hage, 1998, Pesar \& Mahler, 2003, Weiss, 2005) and encourages us to attend to the activities and attitudes of the 'host' population as well as more mobile groups.

In the first part of the paper, we outline the theoretical framework to be used in the paper, drawing on the recent literature on 'return' as well as insights from studies of 
the 'politics of belonging' (Hage, 1998, Yuval-Davis, 2011) and provide an overview of the research project used to generate our findings. In the second part, we examine the relationship of our respondents to their parents’ ancestral homeland, their motivations for travelling there, and, finally, their everyday encounters in Egypt, during a period of social and political upheaval. Here, particular attention is paid to the transnational skills and competencies they employ, as well as, the shifting contextual pressures that inform, and constrain, processes of identification and recognition.

\section{Return mobilities}

As King and Christou note, there has been a recent 'resurgence of interest' (2011: 452) in return mobilities, a range of movements that include everything from permanent migrations back to a place of origin to short-term holidays in an ancestral homeland. This work has generally been informed by insights from the burgeoning literature on trans-nationalism, which has emphasized the ways in which improved transport and communication networks allows growing numbers to maintain more sustained and complex connections across national borders. However, studies of return place a particular emphasis on understanding the reasons for, and impacts of, these forms of 'home-coming', whether as one-off forms of (re)settlement or increasingly as back and forth journeys that involve different generations, periods of time and motivations. Here, Christou \& King’s work (2011: 458-9, but see also, King \& Christou, 2010, King et al, 2011) on the topic offers a useful starting point for thinking about these issues, though at times does tend to conflate categories of people, the reasons for 'return' and the duration of stay. In the first case, they distinguish most 
obviously between 'specific return mobilities of childhood' (Christou \& King, 2011: 459) and second-generation return as adults. Elsewhere, a further distinction is made between movements involving members of 'long-established diasporas', labeled as 'ancestral return', and other migrants. Studying their subjects' motivations has been of particular concern for researchers of 'return mobilities' and these can be broadly categorized as existential (return to 'roots', search for the true self, quest for personal freedom), instrumental (improved lifestyle, life-stage event e.g. marriage, job, study) and external (meet family expectations, fulfill state regulations) reasons (King et al, 2011: 490-4). The first two are of greatest relevance to this paper and are worth discussing in a little more detail.

\section{Reasons for return}

In the former case, many 'return’ movements have been characterised as a desire to 'relocate to a country to which they have always felt bonded by family ties ..., as a project of existential return' (Christou \& King, 2010: 2). When asked to discuss their reasoning, the migrants often reference 'natural' metaphors, such as blood, soil or roots, or, what Christou \& King, label as idiotopy, 'the belonging/longing of a people to/for a unique place' (2006: 824). Interestingly, these forms of expression also permeate the views of many of those who travel 'home' for much shorter periods as part of a movement that has been labelled as 'roots tourism' (Bolognani, 2013: 5).

These movements, and the broader processes of identification they are predicated upon, have also been discussed in relation to the concept of 'diasporic consciousness' (Sökefeld 2006: 265). This is a useful heuristic device that points to the framework of 
everyday and eventful social practices, material objects, forms of language and representations that allow different generations to maintain connections with distant 'homelands', feel part of a wider trans-national network and, in particular circumstances, engender more concerted attempts to explore these places in person. In underpinning the cultivation of particular knowledge, dispositions and skills, which allows individuals to more effectively move between, and feel comfortable in, different places, diasporic consciousness might also be seen as a particular form of socio-cultural capital. As we will show, however, this knowledge of and orientation towards 'other places' does not always mean that trans-national actors are able to operate without constraint when they actually visit, or settle in, them. As we will see, host populations are often key to defining whose claims to belonging are accepted and, as a consequence, whether someone is treated equitably in a given social setting.

Beyond this established body of research on these searches for self, community and place, others have noted more instrumental reasons for 'return'. For instance, Ley and Kobayashi (2005) discuss the views and experiences of Canadian-born second generations 'returning' to Hong Kong. These movements were seen as forms of 'strategic transnationalism' designed to take advantage of the financial and lifestyle opportunities that a busy, exciting global hub can offer to Western-educated migrants with access to local networks. While, however, these types of 'return' may be for prolonged periods, Ley \& Kobayashi warn against viewing them as an end point and, instead, note that remigrations often correspond to a new stage in the life cycle, notably bringing up young children. 
The pursuit of employment opportunities has been a feature of many studies of 'return mobilities’ involving Western-born groups (Carruthers, 2002, Conway \& Potter, 2009, Jain, 2013). In these cases, the second generation is not only able to utilise forms of cultural capital, associated with a Western passport and education, but take advantage of the social capital provided by family and kinship ties. These can often be used to ameliorate some of the challenges of trying to operate in a new, and often more demanding, social setting. This may be a particular issue for female migrants, notably in areas where gender roles are much more closely managed when compared with Western countries (Wong, 2014).

For example, Marta Bolognani’s (2013) study of young British Pakistanis returning to their parent's ancestral homelands, notes how these visits are often viewed by male respondents as a chance to enjoy themselves as affluent tourists, find a 'suitable' mate and exploit their (relative) wealth in business transactions. The activities of female migrants were much more limited and this imbalance is something we also focus on in relation to the Egyptian case.

Two final points are worth noting at this juncture. These categories, existential, instrumental and external, are best seen as ideal types and much research into these issues points to the fact that is usually a combination of reasons that motivates people to ‘return’ (Jain, 2013: 910). For instance, those we interviewed generally talked about both existential and instrumental reasons for wanting to live in Egypt. Likewise, their relocation to Egypt is probably better viewed as a form of life-cycle migration. In this case, we are dealing with the activities of relatively young and well-educated individuals, born in one country, but with strong kinship ties to another, who move for 
extended periods but are generally not tied down by longer-term commitments e.g. family, job.

\section{The politics of trans/national belonging}

The other key issue within the literature that is of primary relevance to our own study concerns the tension between the opportunities offered by mobility and the search for a place (or places) where one can feel comfortable, settled and 'at home’ (King \& Christou, 2011: 454). In the first case, we have already noted how relative affluence, established social networks and 'universalised' forms of cultural capital may offer many advantages to second generations who visit or settle in ancestral homelands. Likewise, these individuals are also seen to benefit from being able to engage with and critically evaluate a range of social and cultural practices (Levitt, 2009: 1238).

In the second instance, while return migration is often viewed as a means through which members of the second generation seek to generate or secure a sense of belonging, these processes are always subject to negotiation and, in many cases, contestation. Therefore, it is crucial that we also acknowledge, and theorise, the role of host populations or institutions in defining hierarchies of belonging. That is, in identifying those who belong, recognising their 'right' to operate (more or less) autonomously in a given social setting and, in doing so, making them feel 'at home'. A useful example of this process comes from the work of Ashley Carruthers (2002) who studied the experiences of Australian-born people of Vietnamese descent (labelled as Viet Kieu) who returned to Vietnam for extended periods. Carruthers observed that 'domestic Vietnamese have an extremely finely honed capacity to spot a 
non-national, who is identifiable by the tiniest departure from locally constituted codes of dress, deportment, speech, and so on' (2002: 431). These acts of boundarymaintenance generate significant costs for the Viet Kieu both economic (they are often over-charged for goods or offered far worse terms when undertaking financial transactions) and psychological (feelings of anger, shame or estrangement). Similar examples can be found in relation to British Sikhs returning to the Indian Punjab (Taylor, 2013) and British Pakistani’s in the Mirpur District of Pakistan (Bolognani, 2013).

Therefore, while many have pointed to the benefits of being able to regularly move across borders, others have noted the extent to which such groups experience a profound sense of dislocation and uncertainty in trying to manage competing reference points and their 'in-between' status. As a respondent in Huang et al's study of 'homecoming' by second and third generation 'migrants' observes; 'Even though I say I can choose to be one side or the other, I also feel as though I don’t belong anywhere. When I'm here in America, most Americans identify me as Korean. When I'm in Korea, most Koreans identify me as American' (Huang et al, 2011: 9). An almost identical view is expressed by a respondent in King and his colleagues study (2011) of second-generation Greeks, born and brought up in Germany, but now living in Greece.

I feel like a foreigner in my own country, but in Germany I am a foreigner too [. . . ] I haven’t accepted completely that I am in my own country, so my conclusion is that, generally, I don’t know [where my home is] (ibid: 498) 
These are good examples of the 'ontological insecurity' (Giddens, 1990: 92) that even the most privileged migrants sometimes have to negotiate as a result of their shifting status. The key point to reiterate is that while mobile groups benefit, in many ways, from opportunities to engage with a variety of cultural forms and social groups, the ability to feel at ease, and at home, in a particular location comes from being recognised as one who belongs 'without question', and this is something that cannot be simply bought or asserted (Hage, 1998). Here, it's worth noting the distinction that Yuval-Davis draws between belonging, which is seen to be ‘critical to people’s emotional balance and well-being' (2011: 294), and the 'politics of belonging'. The latter refers to the struggles to define who belongs to a particular social group or setting and, in the process, lay claim to key allocative and authoritative resources. How, and in what ways, these tensions play out is of course an empirical question, and one we turn to in the second part of the paper, looking at the experiences of British and American-born people of Egyptian descent and their travels to their parents' homeland. In the next section, a brief overview of the research project that generated these findings is provided.

\section{Research Project}

This research is based on 15 extensive semi-structured interviews, 13 in Cairo and two in London during the summer of 2012. All of the respondents had lived in Cairo for between six years and six months, with most having lived there for around four years. In terms of professions, the respondents consisted of: one artist, two film makers, one of them also an Arabic student, three journalists with one also a youth 
worker, two writers, three teachers in private international schools, two business owners, an architect and a barmaid.

Each subject had at least one Egyptian parent, was born and raised in either the UK or US and voluntarily decided to move to Egypt for an extended period. Further commonalities include the fact that all subjects were aged between 25 and 35, and predominately self-identified as middle class or at least were university educated. Their age is significant in that they are mostly the children of migrants who left Egypt in the early 1970s and therefore missed many of the changes that reshaped the country in the last 40 years, such as economic decline and increased religiosity (Eid 2007: 89). This is significant in terms of comparing the Egypt their parents would have grown up in to the Egypt that the second generation eventually encountered.

These facts are important when situating the respondents within a contextual framework and will be used to explore the fluid and shifting ways they discussed their own sense of belonging in relation to different settings and events. In order to assess the evolving attitudes and experiences across time and place, a historical, narrative approach was adopted. Respondents were asked to recount their experiences of the country of their birth, their motivations for travelling to Egypt, and about their encounters with Egypt, both before and during the period of political upheaval that began in January 2011.

\section{Diasporic consciousness}


In this section, we first examine the extent to which the respondents felt a sense of being part of a diaspora when living in the UK or US. Unsurprisingly, there were multiple factors that contributed to these forms of identification with their ancestral 'homelands'. For some, a Muslim identity was more prominent than their Egyptian one, since it was often the reason they may not have engaged in similar activities to their non-Muslim peers when growing up. Alternatively, Coptic respondents explained that they felt that sharing the same religious festivals, as well as having western names, helped them to feel more British or American, thereby pointing to the greater levels of national cultural capital they possess in Western settings (Hage, 1998). However almost all of those we spoke to, whether there was a religious identification or not, expressed a sense of having an Egyptian identity, even if it was based solely on a vague awareness of being connected to the land of pharaohs and pyramids.

In most cases family played the most significant role in bringing about this awareness, with parents often trying hard to cultivate Egyptian culture in the home. Growing up eating Egyptian food was prominent for many. Likewise, decorations, old photos and other artefacts in their houses led to what King and Christou described as a 'memorialization of the place of origin' (2009: 18) in domestic settings. These everyday practice and forms of material culture all significantly contributing towards an imagination of what Egypt was, or might be, like.

Childhood trips to Egypt were also important in forming associations with Egypt and being Egyptian. Positive memories around these trips sometimes referred to their experiences of being part of a large family, which often contrasted with the normally 
small families that they had in the UK or US. For others, trips to Egypt may actually have led to a desire to dissociate with the country as a result of negative experiences tied to feelings of estrangement, confusion and boredom. Haider, 27, an artist from New Jersey, USA, recounted his childhood memories of Egypt:

What I remember from the trip when I was five was mosquitos, heat and visiting families and not understanding anything of what was going on .... During my trip back when I was 13 I got food poisoning and stayed in bed for two weeks. Hence not coming back for 10 years.

Others described their childhood trips as very influential, helping them to form a more questioning or critical outlook. Selma, 29, a journalist and youth worker, from Cambridge, UK described childhood trips to Egypt as having been very formative in terms of shaping her political and social outlook on life.

I felt that I was asking questions about the world earlier than a lot of my friends back in England because of what I was encountering. There would be kids older than me begging to me and I didn't understand. So coming to Egypt was always stressful for those reasons but also really informed who I became.

While associations and identifications with Egypt existed for many during childhood, many respondents spoke about eventually identifying themselves as Arab, and of being part of a wider Arab diaspora. The terrorist attacks in the US in 2001 and the Iraq War appear to have been catalysts for the formation of an Arab diasporic consciousness. Waleed explained that: 
the change started to happen after 9/11. Muslims or Middle Eastern people started to have that 'bad people' image and there was a reaction to that. Muslims and Arabs came together and were being defended by anti-war groups.

Significantly, the Coptic respondents also expressed a heightened sense of Arab consciousness during this time, despite, a common assumption that Coptic communities outside of Egypt often distinguish themselves from the general Arab category because of the way Arab nationalism increasingly became intertwined with Islam in the post-1970 period (Eid 2007: 152).

These discussions point to the complex ways in which a 'diasporic consciousness' emerges, is mobilised and negotiated. In particular, we have noted the interplay of the routine (domestic rituals and artefacts) with those memorable events (family celebrations and holidays) or incidents (geo-political conflict) that more explicitly address question of identity. It is also important to remember that all of these processes are shot through with contradictions and ambiguity and subject to change over time. In the next section, we look to explore this idea, by examining the extent to which these associations and forms of identification might have informed a desire to 'return' to Egypt.

\section{Motivations for 'return' to the 'homeland'}

A 'home desire', whether for a real or mythic place, is a common assumption held about return migration (Brah 1996: 180). Given, however, the rather ambivalent 
relationship many had with their parents' homeland, it is problematic to assume that the respondents decision to relocate to Egypt was part of a self-conscious project of 'returning to origins'. What we can say with much more certainty is that the their own aspirations and expectations are one of the multiple factors shaping their conceptions of belonging in Egypt.

In some cases a search for a sense of self that was not necessarily an Egyptian one may have been more important. Adel, 24, an Arabic student, filmmaker and 'born again’ Muslim from London, explained that a search for a place where he could cultivate his Islamic identity was a major motivating factor for him. Others expressed a search for an 'authentic' way of living in response to what they felt was lacking in the West. George described that when he went travelling through Asia after university '[his] eyes were opened to a more authentic, 'real' way of living, which was removed from [his] hyper-capitalist existence in London', and that, after returning to London for a few months, he felt he wanted to try and experience more of this way of living. Similarly, Haider expressed his disillusionment with life in New York:

I graduated from Art school, went to New York, and was living a complete party life ... and I realised that there was no substance there ... So I decided that I'm leaving. But what else was I gonna do? I thought well I know where things are real I guess and I know where I have a place to go, so I might as well go to Egypt. I felt Egypt represented a more authentic way of living. 
Here, we see echoes of both Wessendorf's (2007) research on second-generation Italians, born in Switzerland, where spiritual and physical 'nourishment' was a key motivation for 'return’ and Gardner’s (1993) study of London-born Bengali’s who contrasted the spirituality of Bangladesh with the capitalist-driven lifestyles of the UK. In these cases, it's worth noting that such evaluations are predicated on an ability to compare and contrast lifestyles and then be able to move towards the one that is seen to offer fulfilment. The idea of social capital also comes to the fore as Haider knows that he has 'a place to go', which will offer some degree of comfort and familiarity, as well as the 'substance' he seeks.

For others the motivating factor for their return was more strategic, an interest in Middle Eastern affairs, a desire to learn Arabic or to gain professional experience in a particular sector. Many expressed something of a double desire to improve their career prospects while wanting to 'give something back', and Egypt - a country that they were familiar with and had connections in - seemed a logical place to do that. In addition to these established social networks that could provide local advice, shelter and sustenance, the relatively cheap cost of living in Cairo meant that many of the respondents felt they would be able to spend more time working for less, or even volunteering, than they could in the UK or the US. There was also the knowledge, gained during previous trips, that they could gain access to people and places in Egypt that they would never be able to in the UK or US. Nabila, 34 and an architect from London, said;

I did two great summers of architectural work experience in Egypt ... [on] projects that would be much harder to get involved with at undergraduate level in the UK... 
If I stayed in London I'd have to live at home and work in an office and just be what they called a 'cad monkey' ii whereas if I went to Egypt I was going to have a year long summer holiday and a great opportunity doing meaningful architectural work.

This is another example of the ways in which such groups are able to exploit both social and cultural capital across trans-national settings, utlising their Western credentials whilst also exploiting established social networks in their ancestral homelands. In this way, rather than displaying a longing to return, many of the second generation were using forms of trans-national capital to take advantage of economic and lifestyle opportunities that were simply not available to their parents or grandparents. However, while most respondents did not show a passionate longing to search for roots, when they did 'return' to their parent's homelands, their encounters with Egypt encouraged them, at least, to reflect on their place within Egyptian society.

\section{Everyday Encounters:}

Everyday encounters with Egypt generated many common experiences among our second generation respondents. The sounds, smells and sights that coloured their experiences, or reminded them of their childhood trips, were often similar, while many spoke about visiting relatives and being made to feel very 'at home'. Both these features point again to the value of both established social networks and the cultivation of a diasporic consciousness in managing activities within a trans-national field. 
On the other hand, their encounters with members of the local population and their incessant probing questions - 'Where are you from?' 'Is your mother or father Egyptian?' - reminded many that they continued to be viewed as 'outsiders'. But the degree to which they felt like an Egyptian or an outsider varied, and it was not always straightforward which category was preferable. For example, the intersection of gender and nationality impacted on the ways in which women, in particular, were treated, with most of the female respondents speaking about how being both Egyptian and 'Western' meant they were perceived as more sexually liberal than Egyptian women, and therefore received sexual propositions on this basis. At the same time, their Egyptian association also meant they could not escape the moralising advice from some Egyptians about how they should behave as Egyptians.

Perceptions, or even laws, that restrict the way certain people are able to experience, and therefore interact with a place are significant. For example, while for most respondents there was constant reassurance that they were Egyptian because their father was Egyptian, for Mariam, 35, a journalist from London, whose mother was Egyptian and father was English, the experience was very different. Mariam described how she felt proud when she was finally able to obtain an Egyptian ID card after the law was amended in 2004 to allow women to pass on their Egyptian nationality to their children. Yet despite now having an Egyptian ID card - making her legally Egyptian - she explained that it made no difference to other people’s perceptions. She described a typical conversation she would have with taxi drivers:

Taxi driver's question: Inti minain? [Where are you from?] 
Mariam's response: Umi Masra wa Abuya Englizi. [My mother's Egyptian and my father's English]

Taxi driver's response: Ah, inti englasiya. London! [Ah, you're English. London!]

Mariam says about these exchanges: It's sexism. It's not even about nationality. It's sexism.

The taxi drivers' rejection of Mariam as an Egyptian are based on patriarchal cultural customs where kinship follows the paternal line, therefore meaning she is not considered kin. This is a form of boundary maintenance that can be usefully analysed in relation to Ghassan Hage’s discussion of official versus practical belonging. He writes 'in the daily life of the nation, there are nationals who, on the basis of their class or gender or ethnicity ... practically feel and are made to feel to be ... less national than others' (1998:52).

Therefore, while such individuals may have been granted official recognition by the state, in the form of a passport or identity card, this does not mean that their claims to belong are recognized by people on the ground. Furthermore, in observing the discomfort that this often generates among those who are excluded, we should also note the sense of agency and power that such encounters offer to members of the majority group. In being recognized as belonging without question, they are able to make judgements about the status of 'others'.

While Mariam was not Egyptian enough, Amirah, 30, from London and a teacher in a private international school was too Egyptian. She explained that because she had an 
Egyptian name, and had developed certain 'Egyptian’ mannerisms after living in Egypt for a number of years, she had to try very hard to prove her 'Englishness' to the parents of her students, who wanted a foreign teacher. In order to confirm her foreign credentials, she eventually resorted to producing a birth certificate that proved not only was she born in England, but also that her mother was English too. In this case, a particularly powerful form of institutionalised cultural capital proved Amirah’s status and allowed her to operate more effectively in this context.

What these examples again point to is the ways in which established hierarchies of belonging operate on different individuals in trans-national settings. As others have shown (Bolognani, 2013, Wong, 2014), moving between Western and non-Western settings may represent a particular challenges for women both in terms of everyday attitudes and wider legislative frameworks.

\section{Managing trans-national capital}

Alternatively, most of the male respondents recognised the fact that they were born, raised and educated in the West was an advantage in navigating their way around many obstacles in Egypt, and expressed an awareness of receiving preferential treatment because of their backgrounds. Haider mentioned how his family were shocked at the ease with which he was able to settle in and set up a life for himself in Cairo, achieving tasks that would cause his family some difficulty. He credited this to his American accent and passport, which he said helped him 'get things done faster', as Egyptians were more likely to assist him as an American than a fellow national. 
In some cases there was a strategic choice made to be 'foreign' to suit particular purposes. George, who had achieved a level of Arabic that meant he was, in most encounters, increasingly able to blend in as an Egyptian, explained that in many situations he would intentionally try to speak in broken Arabic so that people would think he was foreign. He described a situation where he trawled the streets of downtown Cairo asking every doorman in Arabic - and therefore appearing to be a single Egyptian male - if there were any flats available in their building, only to be met with a series of rejections. He then checked the same streets at a later date, this time intentionally breaking his Arabic to sound foreign, and found a flat straight away. As Carruthers notes, for those moving within trans-national social fields 'the highest gains come from being able to play the space in-between, and those who play the game of passing truly well are able to modulate their performances .... to suit the occasion' (2002: 431) and, therefore, secure advantages for themselves.

Yet it would be a mistake to simplify Egypt's relationship with khawagaat (nonEgyptian foreigners) as one of acknowledging and acceding to Western hegemony (Ghannam, 2009). Egypt's changing relationship with the 'west' has produced what Egyptian journalist and blogger, Issandr El Amrani, termed the 'The Khawaya [foreign] Complex', which he explained as being a conflicting attitudes of both 'condescension and resentment' and 'envy and thoughtless emulation' (El Amrani 2011). This is a complex that the second generation Egyptians had to negotiate on a day-to-day basis. While this meant a constant reassessing of each situation in order to try to establish which identity to 'play up or down', many saw their ambiguous status as advantageous. Waleed, described how in his position as head of department in a school, his Egyptian subordinates initially made it clear they disliked having a foreign 
manager, yet once he told them he was originally from Shubra (a working class district in Cairo), the teachers changed their attitude towards him.

They warmed to me once they knew I was from an ordinary Egyptian family like theirs, but they also respected me for my British status and work ethic, which they considered was more professional and much stricter than they were used too.

It could be said that the second generation Egyptians were able to enjoy the benefits of being both Egyptian and, because of their British or American birth, education and accents, British or American. This combination, as one of our respondent explained, of Egyptian blood and Western culture seemed to be considered by some of the Egyptians he encountered as the 'height of Egyptianness' (See also Koning, 2009, Peterson, 2011). This example shows again how particular credentials, forms of knowledge and social contacts can be utilised by the second generation to secure economic and social advantages in ancestral homelands.

However, this ability to draw on trans-national capital means that the second generation often remain visible and subject to ongoing scrutiny by local populations. Moreover, this ‘outsider’ status means that changing socio-economic and political circumstances may have profound impacts on how they are perceived and engaged with. In the final section, we address these issues from another perspective, by focusing on how members of the second-generation engaged with a major 'critical event', the political uprisings that began in January 2011, and, just as importantly, the impact of these wider social transformations on their own sense of self and belonging. 


\section{Encounters with an uprising}

The political uprisings in Egypt that began in January 2011, arguably the most significant political events to have occurred in Egypt for the last 60 years, were the backdrop to this study. The uprisings can be described, to use Veena Das's (1995) term, as a 'critical event', something that causes the possibility of new ways of thinking, and therefore new modes of action, to be able to come about. Many spoke about how the country, and their place within it, changed significantly after these events. One of the ways that Egypt, and in particular Cairo, changed was that the place itself had become imbued with new meaning, with mass demonstrations had been attended and battles had been fought on an old familiar landscape. A number of those we interviewed had been involved to varying degrees, although again many of these activities had a gendered dimension (Winegard, 2012).

Adel and George both described the 'bond' that they felt they developed with Egyptians' during this time and that the initial inclusive sentiments that the Egyptian uprisings were built on - such as 'Ead Wahda' [We are all one hand],-- was something they could fully immerse themselves in. Some recognised the unique contribution they could make to the revolutionary cause through their transnational links and language skills, which could be utilised at this time to raise support for the uprising outside of Egypt. Whatever their level of involvement, for most, the events brought on an increased consideration of their place within Egypt, with many wondering how far they would go for the revolutionary cause. 
Anastasia Christou, in her study on Greek-American 'returning' migrants, speaks about a 'development assignment' that returnees feel the need to fulfil in order to complete their return project and justify their 'ethnic and cultural value’ (2011: 103). While it did not appear this was a motivating factor in wanting to participate in the uprisings, with most choosing to participate because they believed in the cause itself, it seems certain some did feel that their continued involvement went some way to 'earning' themselves an Egyptian identity, or at the very least a right to an opinion on what was happening. Some expressed that they had felt like visitors or observers in Cairo before January 2011, but that through their participation they had an increased sense of belonging in Egypt. George explained that:

I was so excited and inspired by the initial 18 days of the revolution, but I didn't have the rage that I have now having been a part of it ... I hadn't been a victim of the Mubarak years and I guess I wouldn't portray myself as a victim of the SCAF ${ }^{i i i}$ years, but I've seen it and I've been participating in demonstrations that have been attacked and I've been tear-gassed. So I feel that I have much more reason, a stronger reason to be angry. Whereas in the beginning it was more, 'Wow, look at this, these people are rising up' and I wanted to support them and be there to film it and document it, now my priorities have shifted and I'm more concerned with the revolution than with the journalism of the revolution.

George’s heightened sense of belonging was very much based on his increased participation in events on the ground, shifting him from a (relatively) disengaged witness to an active member of 'the people'. With this increased sense of belonging, many became aware of how their discourse about the revolution changed gradually 
from talking about what 'they' need to do, to what 'we' need to do. Through their continued participation in revolutionary activity - be it chanting at demonstrations, being involved in clashes, or simply discussing issues in taxis or coffee shops - a new Egyptian consciousness developed for many.

However, while this close participation in events seemed to foster an increased sense of Egyptianness, the respondents noted that the degree to which they were recognised as Egyptian by other people often varied. After the early demonstrations, in which they described how there had been a real sense of unity amongst people, there was a common awareness that their western association - within the revolutionary context had now gone from being a positive one to a negative one. Many noted that the atmosphere became increasingly nationalistic, and some noticed that even their middle or upper class Egyptian friends who participated in the uprisings - many of whom had lived or been educated in the West - were increasingly adopting a more 'authentic' Egyptian persona. One respondent said that, 'During this time the more Egyptian and the more working class you were, the better.' Another stated that, 'Everyone who once tweeted in English was now tweeting in Arabic. There was certainly a renewed pride in an Egyptian and Arab identity.’

In a very different expression of nationalism, official propaganda often blamed 'foreign hands' for events in Egypt, and state media often warned Egyptians about foreign spies or infiltrators, especially those who spoke Arabic, promoting a discourse of ‘xenophobia as patriotism’ (Galey 2012). ${ }^{\text {iv }}$ Many who had previously acknowledged their preferential treatment as 'Westerners' were now finding this identity had become a stigma that they had to carry, and often had to try and conceal. 
As one respondent put it, his American nationality had become 'like a black spot on [his] identity.'

But it wasn't just that one part of their identity had become stigmatised. Whereas before the unrest claiming to be Egyptian was largely a matter of where your father was born, since the uprisings many felt that their Egyptianness was being judged according to a 'formula', notably in politically active circles. According to Haider:

Now, it almost boils down to arithmetic, getting judged on the summation of all the things you've been involved with. It even gets to the point when you're judged on whether you have a bata'a [national ID card] or not. Like some people who don't have a bata'a...I even find myself looking at them thinking 'you don't have a bata'a?!' And then I'm like, wait a minute, I didn't even have a bata'a until a year ago! I think we're living in a time when identity is in such demand. It's almost like a commodity that you want to get, and you have to do certain things, like learn the language, or get an ID card to get the identity. It's not something that's fluid anymore.

In an atmosphere that many expressed had become more homogenously nationalistic, hierarchies of belonging again shifted with the status of those with multiple allegiances being called into question. Paradoxically, then, just as their participation in the revolutionary movements caused an increased connection in solidarity with some Egyptians, for many of the second generation we spoke to, it also simultaneously increased their 'outsider' status within Egypt as a whole. Put simply, changing political circumstances meant that many of them now struggled to convert 
their transnational capital into benefits on the ground. As a result, articulating a more 'authentic’ Egyptian identity not only expressed solidarity with the revolution but was also a defence against official anti-foreign propaganda and the (potential) judgements of those who status remained 'beyond doubt'.

\section{Conclusion}

The recent rise in global mobility has encouraged scholars to examine how social relations and organisations increasingly move beyond borders so that growing numbers orientate their lives towards different communities and places. This paper has contributed to this endeavour by investigating the experiences of second generation, American and British-born people of Egyptian ancestry, who settled in Egypt for extended periods of time.

Drawing on interview data, the study first analysed the ways in which a diasporic consciousness is generated and nurtured through everyday practices and objects, generally within the home, childhood vacations as well as the reactions of others within 'majority’ populations, whether in the country of 'birth' or ‘origin'. While these processes demonstrate the salience of transnational ties for those born outside the 'country of origin', it was also noted that the second generation have a complex, and shifting, relationship to their parent's homeland, viewing it as a source of frustration and shame as well as community and opportunity. In the latter case, for many of the respondents, the motivation for wanting to visit, or live in, their 'ancestral homelands' could be defined as a form of 'strategic transnationalism' designed to improve life chances, whether economically, socially or spiritually. 
Well educated, and coming from relatively privileged socio-economic backgrounds, these individuals often discussed Egypt as a place where they could be (more or less) comfortable, in both psychological and material terms, by drawing on family connections, local and Western knowledge and economic capital. Notwithstanding these advantages, their ability to fit in with wider society was often constrained by the responses of 'locals', who used more exclusive social categories to position them as 'outsiders'. Here, there were noticeable differences between the ways in which male and female respondents were treated by some members of the 'host' population, with the dress and activities of the latter subject to much more critical scrutiny, notably when claims to Egyptian belonging were being evaluated.

In the second part of the paper, we showed how changing social circumstances, in this case, the period of political upheaval that began in January 2011, impacted on the status of the second generation, as opportunities to effectively contribute to civil society organisations, and prove one’s status as an Egyptian, were mitigated by a climate of increasing nationalist fervour where being identified as 'Western' was potentially damaging. As Levitt \& Glick Schiller (2004) have argued attending to this temporal dimension is crucial and this study shows, 'transnational practices ebb and flow in response to particular incidents or crises' with the attention and energies of trans-national actors 'shifting in response to a particular goal or challenge’ (Levitt \& Glick Schiller, 2004: 1012-13).

In paying particular attention to these shifting hierarchies of belonging we have also highlighted the damaging consequences of not having one’s status recognised in a 
given social setting. This would include material losses (being overcharged or refused credit), the psychological cost of being excluded as well as physical threats or violence. At the same time, it is important to acknowledge the sense of agency and control that comes from being able to make such judgements. This may be a particular issue for members of the host population who, in many cases, cannot access the same range of resources as trans-national migrants. Indeed, the significance of these relations of power have been somewhat overlooked in some of the more celebratory accounts of trans-national mobility and are something that future studies of the topic might investigate in more detail.

\section{Bibliography}

Bolognani, M. 2013. Visits to the country of origin: how second-generation British Pakistanis shape transnational identity and maintain power asymmetries. Global Networks, 14(1): 103-120

Brah, A., 1996. Cartographies of diaspora: Contesting Identities, London: Routledge.

Carruthers, A. 2002. 'The Accumulation of National Belonging in Transnational Fields: Ways of Being at Home in Vietnam', Identities, 9(4): 423 - 444

Christou, A., 2009. Emulating the homeland - Engendering the Nation: Agency, Belonging, Identity and Gender in Second generation Greek-American return migrant life stories. In D. Conway \& R. B. Potter, eds. Return migration of the next generations: 21st century transnational mobility. Farnham: Ashgate. 
Christou, A., 2011. Narratives of place, culture and identity: second-generation Greek-Americans return 'home’, Amsterdam: Amsterdam University Press.

Conway, D., \& Potter, R. (Eds.). 2009. Return migration of the next generations: 21st century transnational mobility. Basingstoke: Ashgate

Das, V., 1995. Critical events: an anthropological perspective on contemporary India, Oxford: Oxford University Press.

Eid, P., 2007. Being Arab: Ethnic and Religious Identity Building among Second Generation Youth in Montreal, Montreal \& Kingston; London; Ithaca: McGillQueen’s University Press.

El Amrani, I., 2011. The Khawaga’s lament. Egypt Independent. Available at: http://www.egyptindependent.com/opinion/khawaga’s-lament [Accessed September 14, 2012].

Galey, P. 2012. Beware foreign spies, Egypt warns, in ridiculous but dangerous ads. Guardian Online. Available at:

http://www.guardian.co.uk/commentisfree/2012/jun/12/beware-foreign-spies-egyptwarns-ads [Accessed September 4, 2012]. 
Ghannam, F. (2009) 'Keeping him connected: globalization and the production of locality in Cairo’ in Singerman, D \& Amar, P (Eds) Cairo Cosmopolitan, Cairo, American University of Cairo Press

Gardner, K. (1993). Desh-Bidesh: Sylheti images of home and away. Man, 28(1): 115.

Giddens, A. (1990) The Consequences of Modernity. Cambridge, MA: Polity.

Hage, G 1998. White Nation, Annandale, NSW, Pluto Press

Jain, S. 2013. For love and money: second-generation Indian-Americans 'return'to India. Ethnic and Racial Studies, 36(5), 896-914.

King, R. \& Christou, A., 2010. Cultural Geographies of Counter-Diasporic Migration: The Second Generation Returns ‘Home’. Sussex Centre for Migration Research; University of Sussex.

Koning, A. (2009) Global Dreams: Class, Gender, and Public Space in Cosmopolitan Cairo. Cairo: American University in Cairo Press.

Levitt, P. 2009. Roots and routes: understanding the lives of the second generation transnationally. Journal of Ethnic and Migration Studies, 35(7), 1225-1242. 
Levitt, P \& Glick Schiller, N. 2004. Conceptualising Simultaneity: A Transnational Social Field Perspective on Society, International Review of Migration, 38(3): 10021039

Levitt, P \& Jaworsky, B. 2007. Transnational Migraton Studies: Past Developments and Future Trends, Annual Review of Sociology, 33: 129-56

Ley, D., \& Kobayashi, A. 2005. Back to Hong Kong: return migration or transnational sojourn?. Global Networks, 5(2), 111-127.

Pesar, P \& Mahler, S. 2003. Transnational migration: Bringing gender in, International Migration Review, 37(3): 812-843

Peterson, M (2011). Connected in Cairo: Growing Up Cosmopolitan in the Modern Middle East. Indiana University Press.

Portes, A, L. Guarnizo \& Landolt, P. 1999. The study of transnationalism: pitfalls and promise of an emergent research field, Ethnic \& Racial Studies, 22(2): 217-237

Sökefeld, M., 2006. Mobilizing in transnational space: a social movement approach to the formation of diaspora. Global Networks, 6(3), 265-284.

Taylor, S. 2013. 'Home is never fully achieved .. even when we are in it!': Migration, belonging and social exclusion within Punjabi transnational mobility, Mobilities, 1-18 
Weiss A. 2005. 'The Transnationalization of Social Inequality: Conceptualizing

Social Positions on a World Scale’, Current Sociology 53(4): 707-728.

Wessendorf, S. 2007 'Roots migrants': transnationalism and 'return'among secondgeneration Italians in Switzerland. Journal of Ethnic and Migration Studies, 33(7), 1083-1102.

Winegar J. 2012. “The privilege of revolution: gender, class, space, and affect in Cairo”. American Ethnologist, 39(1): 67-70

Wong, M. (2014). Navigating return: the gendered geographies of skilled return migration to Ghana. Global Networks, 14(4), 438-457.

Yuval-Davis, N. 2011 The Politics of Belonging, London: Sage

\footnotetext{
'This refers to the knowledge, preferences and skills that enable people to operate effectively in transnational settings, rather than flows of capital across borders.

ii A slang term for someone who does much of the mundane work in an architect's office, generally using CAD software.

iii The Supreme Council of the Armed Forces (SCAF) who took power to govern Egypt after President Hosni Mubarak departed on the $11^{\text {th }}$ February 2011. They remained in official power until the $30^{\text {th }} \mathrm{J}$ une 2011 when Mohamed Morsi became president of Egypt. v See Egyptian State TV anti-foreign propaganda advertisement as an example (http:// www. youtube. com/ watch?v=uX3wqwu6pLA)
} 